\title{
新しい熱線プローブの開発*
}

関 谷 直 樹*1, 松 本彰*1

\section{Development of a New Hot-wire Probe}

\author{
Naoki SEKIYA*2 and Akira MATSUMOTO \\ *2 Department of Mechanical Engineering, Nihon University, \\ 1-8 Kanda-surugadai, Chiyoda-ku, Tokyo, 101-8308 Japan
}

\begin{abstract}
We manufactured a new hot-wire probe (abbreviated as NHP) with two parallel wires placed close together for measuring a transitional boundary-layer flow. The main feature of NHP was that it was much smaller than conventional multi-sensor probes, such as an $\mathrm{X}$-type probe. Thus, the present probe could be regarded as a sensor similar to an I-type probe in configuration; we expected to obtain high spatial resolution for the velocity components. The principle of measurement was very simple so that streamwise and normalwise velocity components were simultaneously obtained from sums and differences of the linearized hot-wire outputs with aid of the look-up matrix method. As a result, we found that although the characteristics between the hot-wire output and flow angle are very complicated, we can obtain simple relations between them if flow angle is confined from $-30^{\circ}$ to $30^{\circ}$. Moreover, we measured velocity profiles in a low Reynolds number turbulent boundary layer using NHP. From results obtained, it was found that NHP is very useful tool for measuring velocities in a thin boundary layer.
\end{abstract}

Key Words: Velocimetry, Hot-wire Probe, Boundary Layer, Turbulent Flow, Low Reynolds Number

\section{1. 粕言}

流速測定に古くから使われている熱線流速計は近年 盛んに使われている LDV やPIV に比べ安価であり， また，トレーサを必要としないため使用も容易である など利点も多い.さらに，ピト一管に比べ風速変動に 対する応答性に優れており，乱流中に含まれる速い変 動を十分に捉えることができるため, 現在でも乱流実 験では久かすことができない，最も一般的であるI型 熱線プローブと称される単線式のプローブはセンサー 部が小さいという特徴から非常に高い空間分解能を持 つが，その構造上 1 万向の速度成分の情報，すなわち 速度の大きさしか得ることができない.これに対し， $\mathrm{X}$ 型， $\mathrm{V}$ 型等の 2 線式熱線プローブは 2 方向の速度成 分の同時計測を可能とするが, 垂直方向のプローブ形 状が大きいことから固体壁近傍における計測が不可能

\footnotetext{
* 原稿受付 2006 年 9 月 27 日.

*1 正員, 日本大学理工学部(画101-8308 東京都千代田区神田 駿河台 1-8).

E-mail : sekiya @mech.cst.nihon-u.ac.jp
}

であり，遷移境界層のような薄い境界層での使用は困 難である. 2 線式熱線プローブと同様に, 2 方向の速度 成分の同時計測が可能な熱式流速計として $2 つ の$ 熱膜 をセンサーとしたスプリット・ホットフィルムプロー ブがある. このスプリット・ホットフィルムプローブ は垂直方向の大きさが約 $150[\mu \mathrm{m}]$ とX型熱線プローブ に比べ小さかが，熱膜流速計は熱線流速計に比べ風速 変動に対する応答性が劣るため, 速い変動を含む流れ 場での使用には不向きである，そこで，我々は境界層 遷移実験で使用することを前提とし，I型熱線プロー ブと同程度の大きさを有し，かつ 2 方向速度成分が同 時に計測できる新しい熱線プローブを考案, 試作した. このプローブは 2 本の熱線を近接かつ平行に張ったも ので，“近接 2 線式熱線プローブ” と称している. 本 プローブは 2 本の熱線を平行に配置することで垂直方 向の大きさを I 型熱線プローブと同程度の約 $10[\mu \mathrm{m}]$ と 非常に小さくすることを可能にした.

本研究の目的は, 近接 2 線式熱線プローブの出力特 性を詳細に調へ，較正法と計測システムを確立するこ とである. 結果として, 本プローブの出力特性は簡単 
な較正実験から得ることができ，また，熱線加熱回路 も I 型熱線プローブ用回路を大きく変えることなく計 測システムを構筑できた. さらに，本プローブの有用 性を確認するために, 低レイノルズ数乱流境界層の速 度分布を測定した. 得られた結果は, 他の研究者によ る結果 ${ }^{(2)}{ }^{(3)}$ (5) と非常に良く一致しており, さらには本 プローブの空間分解能の高さを明らかにするものであ った. したがって, 既存の X 型熱線プローブと比較す ると, I 型熱線プローブの計測可能範囲と同程度の固 体壁近傍まで 2 方向の速度成分の計測ができるという 優位性から，本プローブは境界層遷移の研究において 非常に有用なツールであることがわかった.

\section{2. おもな記号}

$Q_{1}, Q_{2} \quad$ ： 熱線から気流に対する放熱量 [J]

$\Sigma Q, \Delta Q ：$ 放熱量の和および差 [J]

$E_{H W 1}, E_{H W 2} ：$ 熱線の加熱回路の出力電圧 $[\mathrm{V}]$

$\Sigma E_{H W} \quad$ ：加熱回路の出力電圧の和

$$
\left(=E_{H W 1}+E_{H W 2}\right)[\mathrm{V}]
$$

$\Sigma E_{o}, \Delta E_{o} \quad ：$ 線形化出力電圧の和および差 $[\mathrm{V}]$

$x \quad$ : 座標原点 $o$ からの主流方向距離

[m]

$y \quad$ ： 壁面からの垂直距離 [m]

$z \quad:$ 平板横幅方向の距離 $[\mathrm{m}]$

$\theta \quad:$ 風向 $[\mathrm{deg}]$

$U_{0} \quad$ : 主流速度 $[\mathrm{m} / \mathrm{s}]$

$U, V:$ 平均速度の $x$ および $y$ 方向成分

$[\mathrm{m} / \mathrm{s}]$

$U_{\theta} \quad$ ： 風速の大きさ $\left(=\sqrt{U^{2}+V^{2}}\right)[\mathrm{m} / \mathrm{s}]$

$u^{\prime}, v^{\prime}$ : 変動速度の $x$ および $y$ 方向成分 $[\mathrm{m} / \mathrm{s}]$

$\delta \quad ：$ 境界層厚さ $[\mathrm{m}]$

$\delta_{1} \quad$ : 排除厚さ $[\mathrm{m}]$

$\delta_{2} \quad$ : 運動量厚さ $[\mathrm{m}]$

$v \quad:$ 動粘性係数 $\left[\mathrm{m}^{2} / \mathrm{s}\right]$

$R \delta_{2} \quad$ : 運動量厚さレイノルズ数$$
c_{f}: \text { 局所摩擦係数 }
$$$$
\Pi \text { ： 伴流パラメータ }
$$$$
u_{\tau} \text { : 摩擦速度 }\left(=U_{0} \sqrt{c_{f} / 2}\right)[\mathrm{m} / \mathrm{s}]
$$

\section{3. 近接 2 線式熱缐プローブ}

$3 \cdot 1$ 概要 試作した近接 2 線式熱線プローブの概 要を図 1 に示す. プローブはセンサー部 $0.4[\mathrm{~mm}]$ を残 し，銅めっきを施した直径 $2.5[\mu \mathrm{m}]$ のタングステン線 (以下, 熱線と呼ぶ)2 本をセンサ一部が近接かつ平行に
なるように設置し, 両端を直径 $0.14[\mathrm{~mm}]$ のプロングの 先端に半田付けしてある.2本の熱線の間隔を約 $5[\mu \mathrm{m}]$ とすることでセンサー部の大きさを I 型熱線プローブ と同程度の約 10 [ $\mu \mathrm{m}]$ にした. センサー部の隙間には充 填剂を満たしており，風向に対する感度を上げている. 充填剤には絶縁，而熱，熱伝導性に優れたものを使用 することで両熱線を熱的に結合し，熱的時定数を小さ くした. なお，熱線加熱回路を含む正弦波テストでは 周波数特性が約 $10[\mathrm{kHz}]$ まで保障されることを確認し た.

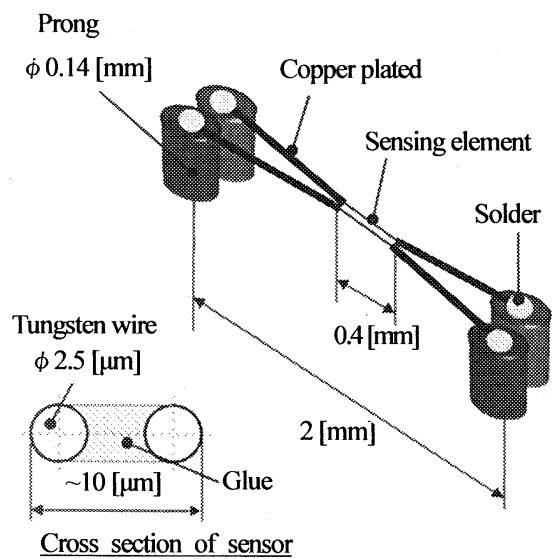

Fig. 1 Schematic diagram of the new hot-wire probe.

$3 \cdot 2$ 測定原理 図 2 に示すように, 本プローブ は2 本の熱線HW1 およびHW2 の中心軸を通る面をセ ンサー面とし，他のプローブと同様にセンサー面の接 線方向の速度成分の影響は小さいものとして扱う。風 向の基準はセンサー面の法線方向を $\theta=0^{\circ}$ と決める.

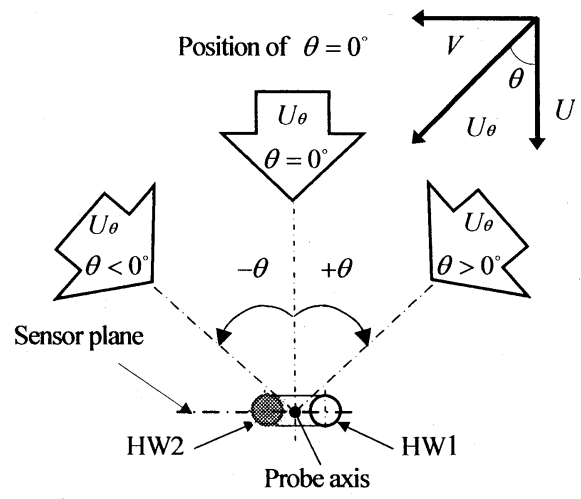

Fig. 2 Definition of sensor plane and its position to flow direction. 
2 本の熱線はそれぞれ定温度型加熱回路(以下， CTC と略す)により加熱されており, 熱的平衡状態を保つと 仮定する. 気流によるそれぞれの熱線からの放熱量 $Q_{1}$ と $Q_{2}$ は, $\theta$ の変化に対し 2 本の熱線の気流に対する投 影放熱面積が変化するため, $Q_{1}$ と $Q_{2}$ の間に差が生じ, この差は $U_{\theta}$ と共に増減すると考えられる. 一方, $U_{\theta}$ の変化に対しては I 型熱線プローブ同様， $Q_{1}$ と $Q_{2}$ は 共に増减する. 結果として, 放熱量の和 $\Sigma Q$ および差 $\Delta Q$ は次の関数関係で表わされると考えられる.

$$
\begin{aligned}
& \Sigma Q=Q_{1}+Q_{2}=f\left(U_{\theta}, \theta\right) \\
& \Delta Q=Q_{1}-Q_{2}=g\left(U_{\theta}\right) \cdot \Theta(\theta)
\end{aligned}
$$

ここで, 式(1)の関数 $f$ の中に $\theta$ を含めた理由はセンサ 一部断面が楕円形であるため, $\theta$ の影響を受けると考 えられるからである.これら式(1)および式(2)の関数 $f$, $g$ および $\Theta$ の形を較正実験から簡単に求めることがで きれば, $\theta$ およびU⿻ 求めることができる. しかし, 我々が実際に扱うことのできる量はこれら $Q$ および $Q_{2}$ に相当する CTC の出力電圧であるため, 次に示す 計測システムを構築した.

$3 \cdot 3$ 計澌システム 近接 2 線式熱線プローブの 計測システムは図 3 に示すように 2 つの CTC, 加算・ 差分アンプおよびリニアライザーから構成される.
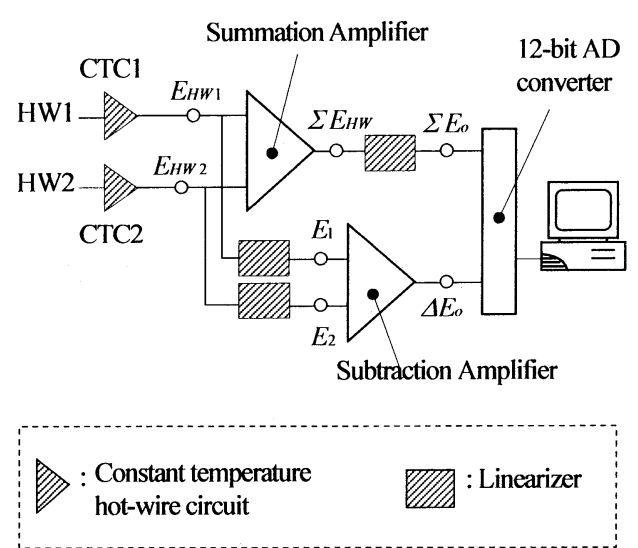

Fig. 3 Data acquisition system.

それぞれの CTC の出力電圧 $E_{H W 1}, E_{H W 2}$ およびこれ らの和である $\Sigma E_{H W}$ は $U_{\theta}$ に対して 1 型熱線プローブ と同様に, 式(3)に示す King の式で知られる一般的な $\mathrm{n}$ 乗則に従うものとする.

$$
E_{H W}{ }^{2}=B+C U_{\theta}{ }^{n}
$$

ここで, $B$ および $C$ は較正定数で一般的に温度の関数 である， $\Sigma Q$ に相当する出力電圧 $\Sigma E_{o}$ は $\mathrm{CTC} 1$ と CTC2 の出力電圧の和 $\Sigma E_{H W}$ が式(3)に基づくリニアラ イザーによって線形化され，出力される.一方， $\Delta Q$ に 相当する出力電圧 $\Delta E_{o}$ は $\mathrm{CTC} 1$ および CTC2 $の$ 出力電 圧をそれぞれ線形化した後 $\left(E_{1}\right.$ および $\left.E_{2}\right)$, 差分アンプ

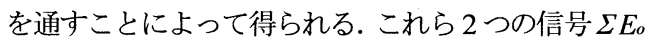
および $\Delta E_{o}$ は 同時に 12bit-A/D 変換器によって取り 込まれ,パーソナルコンピュータに送られる. しかし， $\Sigma E_{o}$ が $U_{\theta}, \theta$ を陰に含んでいるためリアルタイムで $U_{\theta}$ と $\theta$ を求めることは困難である，そこで 5 - 1 に示 す較正法に工夫をするとともに， $\theta$ の取得にマトリッ クス参照法を用いた。 $\Sigma E_{o}, \Delta E_{o}$ からマトリックス参 照法を用いて $\theta, U_{\theta}$ を得る流れを図 4 に示す.

$12 \mathrm{bit}-\mathrm{A} / \mathrm{D}$ 変換器によって取り込まれる $\left(\Sigma E_{o}, \Delta E_{o}\right)$ の 全ての可能な整数值の組み合わせ $(i, j)$ に対応する $\theta$ の值を 5 - 1 に示寸式(10)および式(11)の較正曲線より 計算し, 予めコンピュータのメモリ上に $\theta[i][j]$ のマト リックス $(4096 \times 4096)$ を用意しておく. 次に, 実測か ら得られる $i$ および $j$ を用いてメモリ上に用意した $\theta[i][j]$ のマトリックスから $\theta$ の值を取り出す. 得られ た $\theta$ と $\Sigma E_{o}$ を用いて式(10)の較正曲線より $U_{\theta}$ が求ま る.これら $U_{\theta}, \theta$ より 2 方向の速度成分 $U, V$ は簡単 な成分分解から得ることができる.

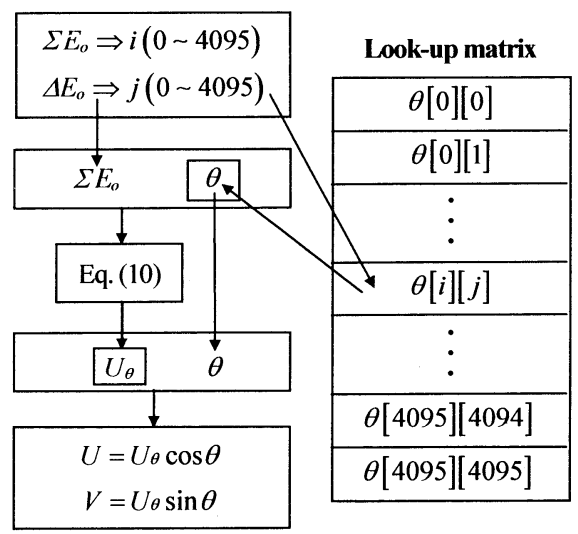

Fig. 4 Schematic diagram of look-up matrix method.

以上の方法により, 計測の際に時間を要する $\theta$ の算出 を省略することができ, $10[\mathrm{kHz}]$ 程度の高速サンプリ ングに対してもリアルタイムで精度の良い $U, V$ の測 定が可能となる. 


\section{4. 実験装置および方法}

4-1 風洞および平板 近接 2 線式熱線プローブ の特性実験およびプローブの有用性を確認するために 行った低レイノルズ数乱流境界層の速度分布測定実験 は遷袳境界層実験用の回流型風洞で行った．風洞は図 5 に示すように $0.45[\mathrm{~m}] \times 1[\mathrm{~m}] \times 3.1[\mathrm{~m}]$ の測定部を持 ち，この中に幅 1 [m], 長さ $2.5[\mathrm{~m}]$ のベークライト製 の平板が垂直に設置されている．測定部内の主流の残 留乱れは $U_{0}=7[\mathrm{~m} / \mathrm{s}]$ のとき $0.1 \%$ 以内である. なお， プローブは回転機構を有するトラバース装置に設置し ており，プローブを回転させることにより任意の風向 を設定することができる.

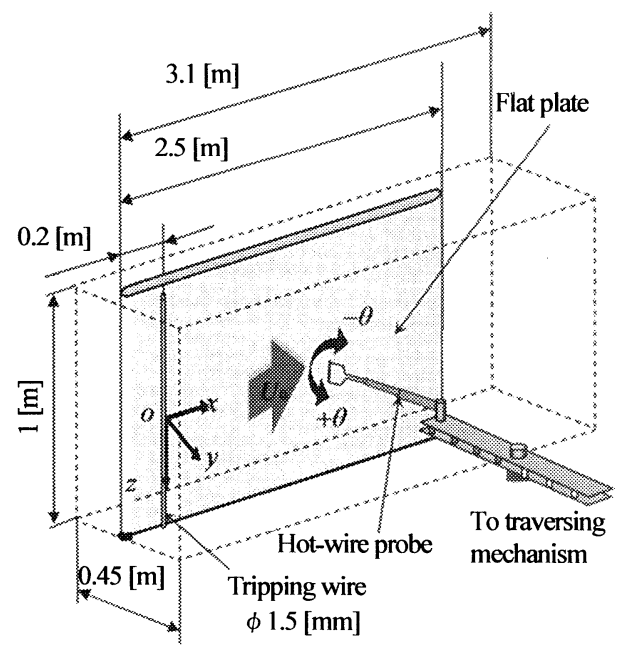

Fig. 5 Schematic diagram of experimental apparatus.

\section{4-2 近接 2 線式熱線プロ一プの特性実㰸 本プ} ローブの出力特性実験は風洞測定部内の一様流中にお いて，プローブを $-70^{\circ}<\theta<70^{\circ}$ の範囲で回転させて 行った. まず初めに, 各 $\theta$ において式(3)の関係が成り 立つかどうかを確認し, 次に $\theta=0^{\circ}$ の位置において $E_{H W 1}, E_{H W 2}$ および $\Sigma E_{H W}$ の線形化を行った. その後, $\Sigma E_{o}, \Delta E_{o}$ のU $U_{\theta}$ および $\theta$ に対する変化を詳細に調べ, 式(1)の $f$ および式(2)の $g$, $\Theta$ の関数形を求めた.

\section{$4 \cdot 3$ 低レイノルズ数乱流境界層速度分布洎定実唫}

低レイノルズ数乱流境界層の速度分布測定は平板 前縁より $0.2[\mathrm{~m}]$ 下流位置の平板上に乱流促進装置と して直径 $1.5[\mathrm{~mm}]$ のトリッピングワイヤーを設置し, 行った. 速度分布の測定位置は $x=0.60[\mathrm{~m}], 0.75[\mathrm{~m}] お よ$ び $0.90[\mathrm{~m}]$ の風洞中央断面とし， $U_{0}=7[\mathrm{~m} / \mathrm{s}]$ とした.
相当する $R_{\delta}$ はおよそ 1000 である. $c_{f}$ および $\Pi$ の算 出には，精度の良い実測から得られた $\delta_{1}$ および $\delta_{2}$ を 用いた積分法による Tani-Motohashi の解析法 ${ }^{(1)}$ を使用 した. 解析法の概略は以下の通りである.

境界層の速度分布は, 境界層の外縁で $\partial U / \partial y=0$ と なる対数則と Lewkowicz $\sigma$ 伴流関数を合成した

$$
\begin{aligned}
\frac{U}{u_{\tau}}= & \frac{1}{\kappa} \ln \frac{u_{\tau} y}{v}+C-\frac{1}{\kappa} \frac{y^{2}}{\delta^{2}}\left(1-\frac{y}{\delta}\right)\left(1-2 \frac{y}{\delta}\right) \\
& +\frac{2 \Pi}{\kappa} \frac{y^{2}}{\delta^{2}}\left(3-2 \frac{y}{\delta}\right)
\end{aligned}
$$

を用いる.ここで,

$$
Z=\kappa \frac{U_{0}}{u_{\tau}}=\kappa \sqrt{\frac{2}{c_{f}}}, s=Z-2 \Pi-\kappa C
$$

とおくと， $\delta$ および $\delta_{2}$ は式(4)の速度分布から

$$
\begin{aligned}
& \delta_{1}=\frac{v}{U_{0}} \frac{\xi}{\kappa} \exp (s) \\
& \delta_{2}=\frac{v}{U_{0}} \frac{1}{\kappa}\left(\xi-\frac{\eta}{Z}\right) \exp (s)
\end{aligned}
$$

とそれぞれ表わされる.ここで， $\xi$ および $\eta$ は

$$
\xi=\frac{59}{60}+\Pi, \eta=\frac{8437}{4200}+\frac{667}{210} \Pi+\frac{52}{35} \Pi^{2}
$$

である. 式(6)および式(7)の $\delta$ およよ゙ $\delta_{2}$ に実測された 值を使い，これら 2 式を満たすように $Z$ を反復計算に よって求め, $c_{f}$ および $\Pi$ を決定する. しかし, 低レ イノルズ数の乱流境界層では粘性底層の影響を無視す ることはできず，実測值 $\delta$ および $\delta_{2}$ は

$$
\begin{aligned}
& \delta_{\mathrm{lc}}=\delta_{1}-50.63 \frac{v}{U_{0}} \\
& \delta_{2 \mathrm{c}}=\delta_{2}+\left(50.63-\frac{136.47}{\kappa Z}\right) \frac{v}{U_{0}}
\end{aligned}
$$

と修正され，式(おおよび式(7)の $\delta 1$ および $\delta_{2}$ をそれぞれ $\delta_{\mathrm{ic}}$ および $\delta_{2 \mathrm{c}}$ に置き換えて計算する必要がある.

得られた結果は本実験の I 型熱線プローブによる結

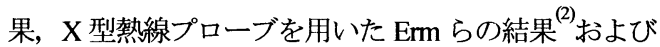
Spalartによる DNS の結果 ${ }^{(3)}$ と比較, 検討した. 


\section{5. 実険轺果および考察}

\section{$5 \cdot 1$ 近接 2 楾式熱線プローブの特性実験結果}

初めに, $\theta$ に対する $E_{H W 1}$ と $E_{H W 2}$ の変化から, センサ 一面が主流に対して垂直となる $\theta=0^{\circ}$ の位置を定めた. このときの結果が図 6 で, $U_{0}=7[\mathrm{~m} / \mathrm{s}]$ の一様流中にお ける $E_{H W 1}$ および $E_{H W 2}$ の $\theta$ に対する変化である. 両者 は共に X 型熱線プローブの 2 倍の周期 $360^{\circ}$ を持ち, 逆 位相になる. $\theta=0^{\circ}$ の位置は図 2 に示すセンサ一面と $\theta$ の関係から $E_{H W 1}$ および $E_{H W 2}$ が最大出力をとる位 置の中心として求まる.

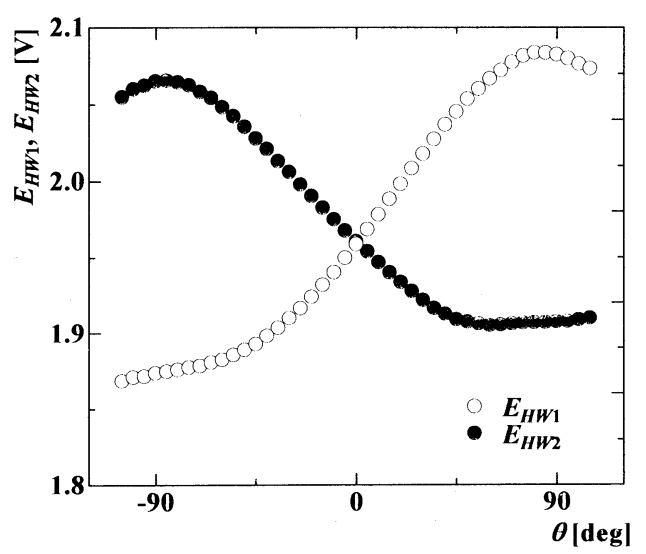

Fig. 6 Characteristic curves of each output of CTC to flow direction at $U_{0}=7[\mathrm{~m} / \mathrm{s}]$.

次に $\theta=0^{\circ}$ の位置において $E_{H W 1^{2}}{ }^{2}, E_{H W 2^{2}}{ }^{2}$ おび $\Sigma E_{H W}^{2}$ の $U_{\theta}{ }^{n}$ に対する関係を調べたところ, いずれも $n=0.4$ (一般的に I 型熱線プローブでは $n=0.45$ )の指数を とる直線関係で表わされ，式(3)の $\mathbf{n}$ 乗則に従うことが わかった. そこで, $\theta$ をパラメータとして $U_{\theta}{ }^{0.4}$ に対す る $\Sigma E_{H W}{ }^{2}$ の変化を調べた. 図 7 がその結果である. い ずれの $\theta$ においても $\Sigma E_{H W}{ }^{2}$ は $U_{\theta}{ }^{0.4}$ に比例し, 式(3)の 関係が成り立つことが確認できる. しかし， $\theta=-70^{\circ}$ の大きな風向では仮想原点 $U_{r}{ }^{0.4}\left(=-C / B: U_{r}\right.$ は特性速 度)が横軸の右方向にずれている.この $U_{r}^{0.4}$ のずれは, $\theta=0^{\circ}$ での線形化処理の後, $\theta$ が大きく変化し, ある 範囲を超えると, 出力電圧と風速の直線関係が原点を 通過しないことを意味している.

そこで, $U_{r}^{0.4}$ の $\theta$ 依存性を調べた. 図 8 に示すよう に $U_{r}{ }^{0.4}$ は $-30^{\circ}<\theta<30^{\circ}$ で $U_{r}^{0.4} \fallingdotseq-2.50\left[(\mathrm{~m} / \mathrm{s})^{0.4}\right]$ と 一定值をとるが, $\theta$ がこの範囲外では $U_{r}^{0.4}$ は大きくな り，一定值からはずれる.この結果から，本プローブ の使用範囲を $U_{r}$ が一定, 寸なわち $\theta=0^{\circ}$ における線形
化がそのまま適用できる $-30^{\circ}<\theta<30^{\circ}$ に制限するこ とで較正曲線が非常に簡単になることが期待できる. この範囲は既存のX型熱線プローブの使用限度とほぼ 同程度である.

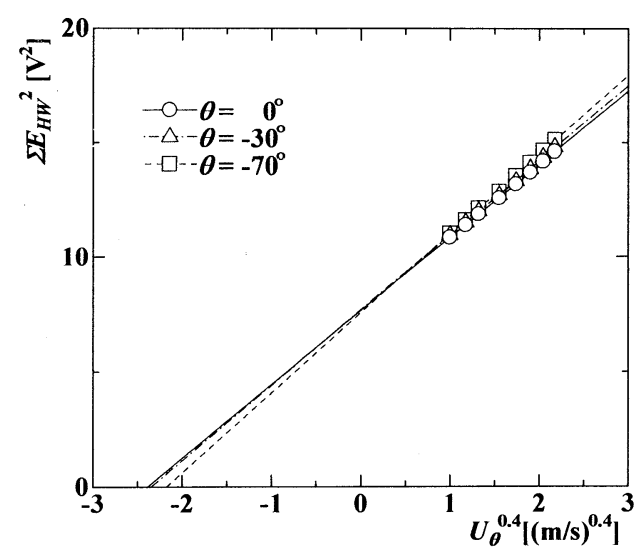

Fig. 7 Relations of $\Sigma E_{H W}^{2}$ for $U_{\theta}^{0.4}$.

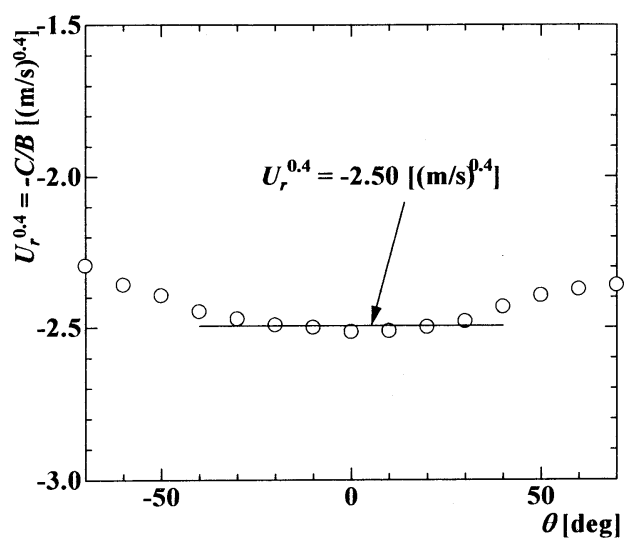

Fig. 8 Variation of $U_{r}^{0.4}$ versus $\theta$.

図 9 は $\Sigma E_{H W}$ の線形化出力電圧 $\Sigma E_{o}$ の $U_{\theta}$ に対する 変化を $\theta$ をパラメータとして調べた結果である. 上記 範囲内のいずれの $\theta$ においても $\Sigma E_{o}$ は原点を通る直 線で近似でき， $\theta$ の変化はその傾きだけに影響を与え ることを示している.この結果は, 本プローブの使用 範囲を $-30^{\circ}<\theta<30^{\circ}$ と制限することで式(1)に相当す る $\Sigma E_{o}$ と $U_{\theta}$ の関係を

$$
\Sigma E_{o}=f(\theta) \cdot U_{\theta}
$$


のように簡単に表わすことができることを示している. 一方， $\Delta Q$ に相当する $\Delta E_{o}$ の $\theta$ に対する変化は図 10 に示すように正弦関数で近似することができ，その振 幅 $g$ は $U_{\theta}$ が小さくなると共に小さくなっていく.こ れらの結果から, 式(2)に相当する $\Delta E$ 。 と $\theta$ の関係は

$$
\Delta E_{o}=g\left(U_{\theta}\right) \cdot \sin \theta
$$

のように簡単に表わすことができる.さらに，式(8)に 含まれる $f(\theta)$ の変化と式(9)の中に含まれる $g\left(U_{\theta}\right)$ の 変化をそれぞれ図 11 および図 12 に整理した. これら の結果から, $f(\theta)$ および $g\left(U_{\theta}\right)$ の関数形は図中に示 すように, それぞれ $\theta$ と $U_{\theta}$ の 2 次関数となる.

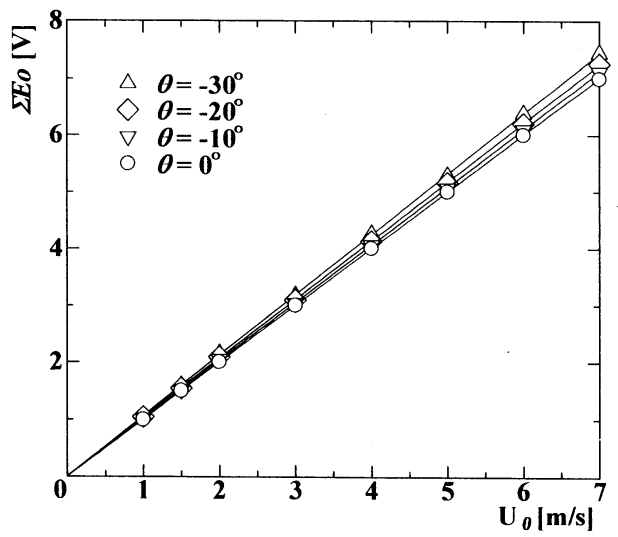

Fig. 9 Calibration lines of $\Sigma E_{o}$ versus $U_{\theta}$.

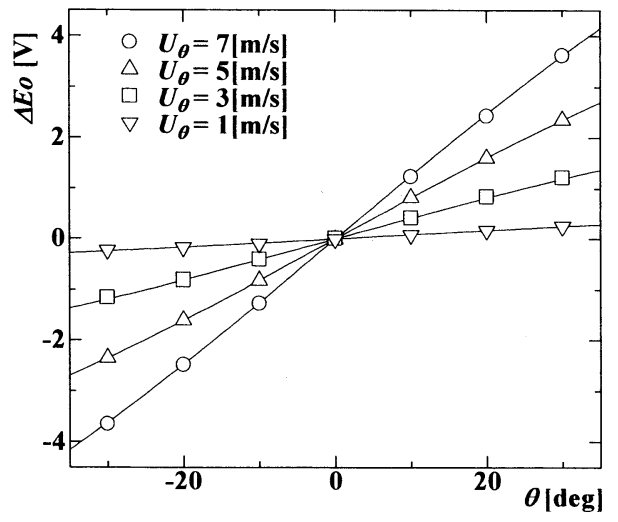

Fig. 10 Calibration curves of $\Delta E_{o}$ versus $\theta$.

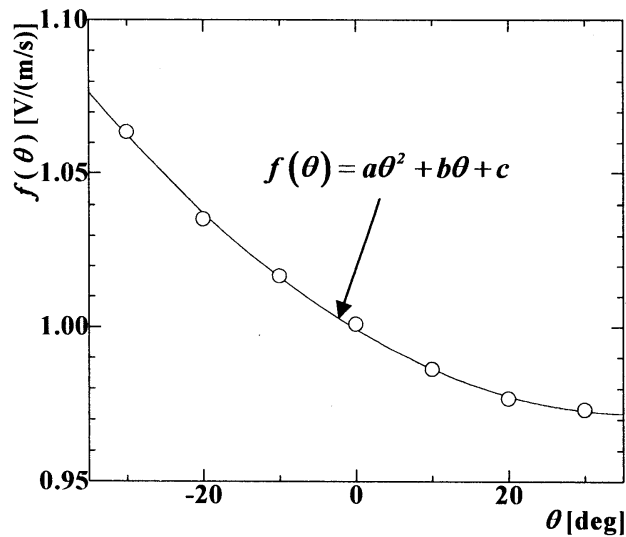

Fig. 11 Calibration curve of $f(\theta)$ versus $\theta$.

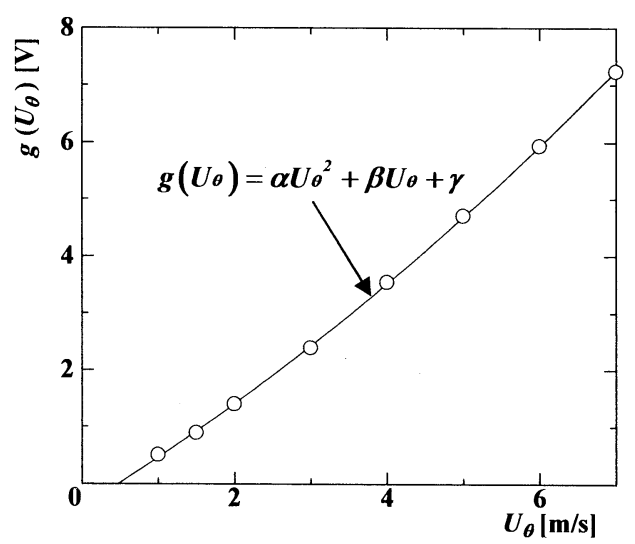

Fig. 12 Calibration curve of $g\left(U_{\theta}\right)$ versus $U_{\theta}$.

以上の較正実験から，式(1)および式(2)に相当する $\Sigma E_{o}, \Delta E_{o}$ と $U_{\theta}, \theta$ の関係はそれぞれ次の関係式で 表わされる.

$$
\begin{aligned}
& \Sigma E_{o}=\left(a \theta^{2}+b \theta+c\right) U_{\theta} \\
& \Delta E_{o}=\left(\alpha U_{\theta}^{2}+\beta U_{\theta}+\gamma\right) \sin \theta
\end{aligned}
$$

ここで, $a, b, c$ および $\alpha, \beta, \gamma$ はそれぞれ較正定 数である. これらの較正式から $\theta[i][j]$ を作成し, マト リックス参照法を用いて $\theta$ および $U \theta$ を実測し， $U, V$ を計算した. 結果は $U, V$ ともに $0.5 \% \mathrm{FS}$ 内の精度で求 めることができた。 このことは，本較正法は簡単なわ りに十分な精度で較正曲線, 式(10)と式(11)を得ること ができるということを示している. 


\section{5 -2 低レイノルズ数乱流境界層の速度分布䁌定結}

果 本プローブを用いた流れ場の測定例として低 レイノルズ数乱流境界層の速度分布測定を選んだ.こ の理由は, 境界層厚さが比較的薄い乱流場であること, そして，これまでに多くの研究者による測定例があり 比較しやすいことによる.図13 は内層スケールで表し た主流方向の平均速度分布である. 図中の実線は計算 速度分布であり, バッファ層には Spalding が提案した 速度分布 ${ }^{(4)}$ を, 対数領域から後流にかけては式(4)に示 したTani らが提案した速度分布 ${ }^{(1)}$ を用いた. 得られた 結果はいずれの $R_{\delta}$ においても $y^{+}<10$ の粘性底層の 領域まで I 型熱線プローブと同様に精度良く計測でき ていることが計算速度分布との比較からわかる. 同様 な条件下で行った ErmらのX型熱線プローブによる結 果と比較すると, 本プローブはX 型熱線プローブでは 測定不可能である $y^{+}<10$ の壁面近傍においても計測 が可能であることが明らかである.

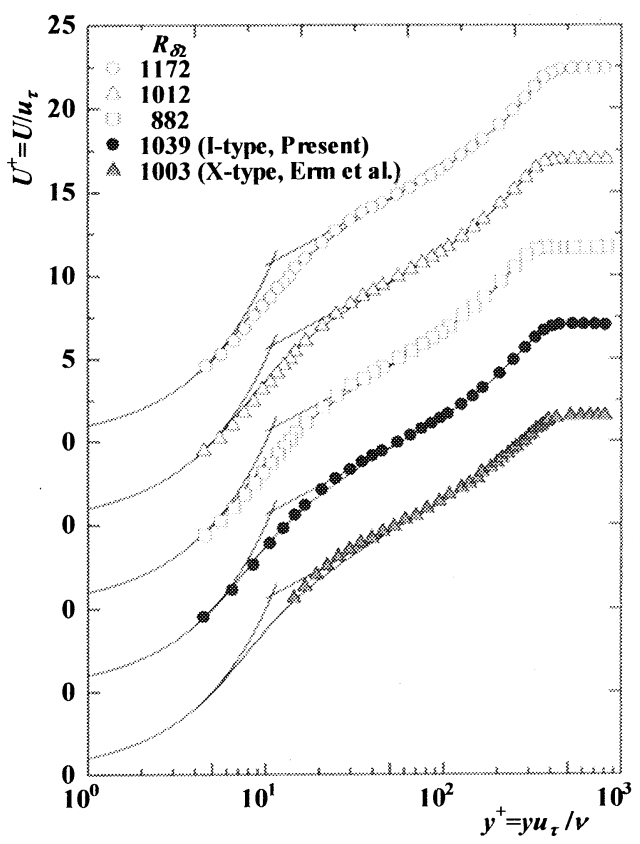

Fig. 13 Mean velocity profiles $U^{+}$versus $y^{+}$.

さらに, 前述の Tani-Motohashi の解析法を用いて求め た $c_{f}$ および $\Pi$ の $R_{\delta}$ に対する变化を図 14 および図 15 に示す. 本プローブによる $c_{f}$ およびクは KármánSchoenherr の実験式, I 型熱線プローブによる結果およ びPurtell らの実験結果 ${ }^{(5)}$ と良く一致しており, 平均速 度分布を精度良く測定できていることが明らかとなっ た.

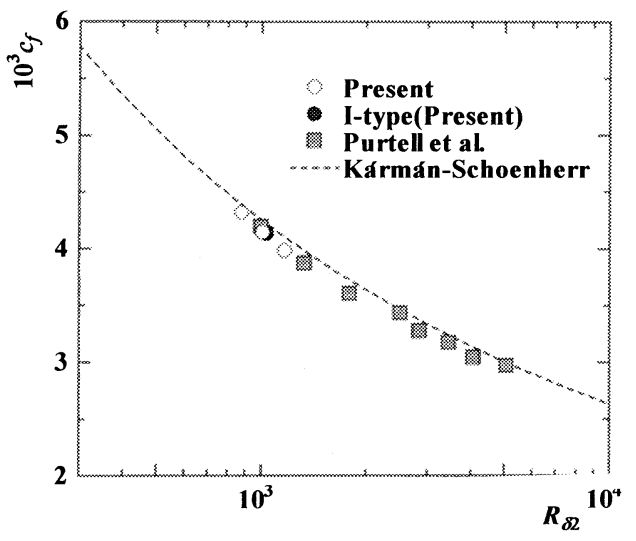

Fig. 14 Variations of skin friction coefficients $c_{f}$ versus $R \delta 2$.

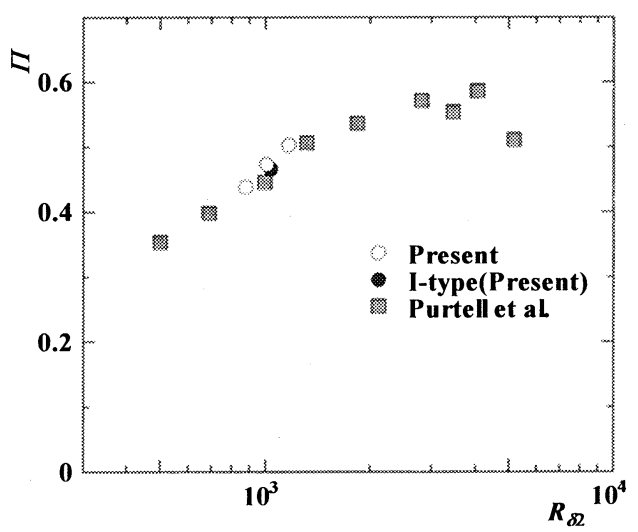

Fig. 15 Variations of wake parameters $\Pi$ versus $R \delta 2$.

次に本プローブが速度変動を十分な精度で計測する ことができるかどうかを図 16, 図 17 に示す外層スケ 一ルで表わした変動速度 $u^{\prime} / u_{\tau}, v^{\prime} / u_{\tau}$ およびレイノル ズ応力 $-\overline{u v} / u_{\tau}^{2}$ の分布から検討する. 本プローブによ って得られた変動速度およびレイノルズ応力はいずれ の $R_{\delta 2}$ においても Spalart の DNS の結果と比べると幾 分小さいものの, I 型熱線プローブによる結果および Erm らのX型熱線プローブによる結果との一致は良好 であることがわかる.これらの結果は本プローブが変 動速度に関しても十分な精度で計測できていることを 示している. さらに, 図 18 に示寸内層スケールで表わ した $u^{\prime} / u_{\tau}$ の分布から, 本プローブは粘性応力の支配 的な壁面近傍の領域まで変動速度も精度良く計測でき ることが明らかとなった. 以上の乱流境界層の平均速 度, 変動速度測定加, 薄い境界層内の速度分布の測 
定に対して近接 2 線式熱線プローブの有用性が示され た.

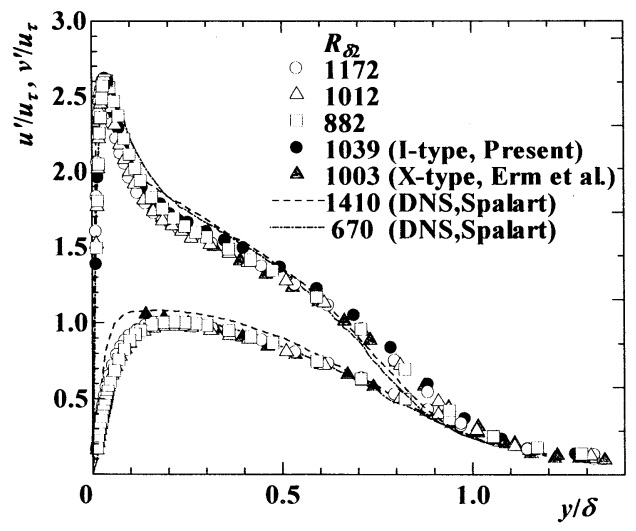

Fig. 16 Distributions of turbulent velocities $u^{\prime} / u_{\tau}$ and $v^{\prime} / u_{\tau}$ versus $y / \delta$.

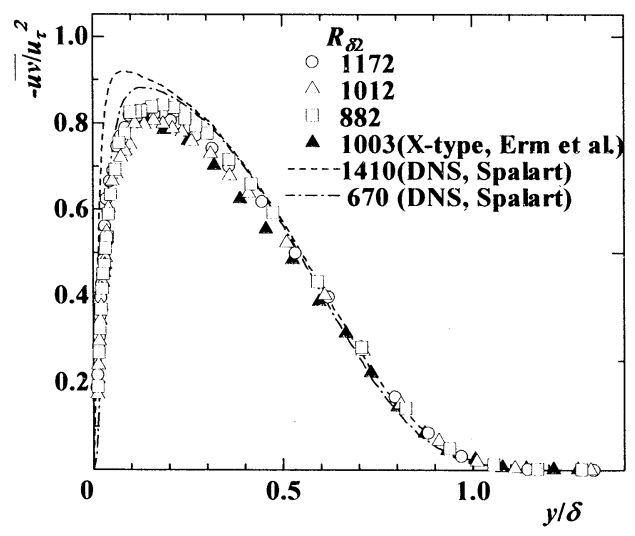

Fig. 17 Distributions of Reynolds stress $-\overline{u v} / \boldsymbol{u}_{\tau}{ }^{2}$ versus $y / \delta$.

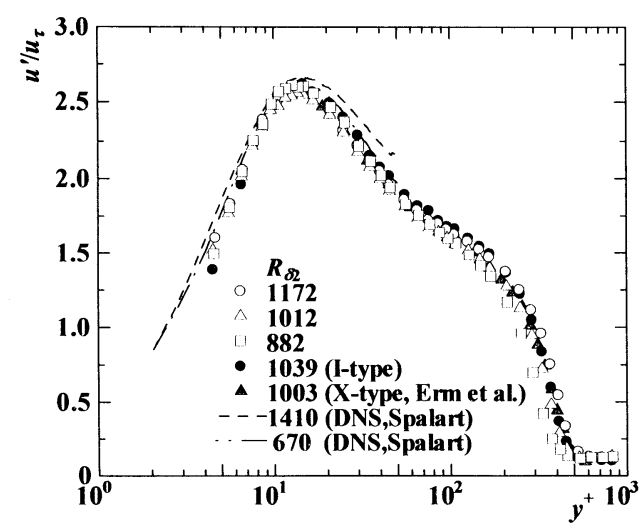

Fig. 18 Distributions of turbulent velocities $u^{\prime} / u_{\tau}$ versus $y^{+}$.

\section{6. まとめ}

試作した近接 2 線式熱線プローブの出力特性を詳細 に調べた結果，および本プローブを用いた流れ場の測 定例として低レイノルズ数乱流境界層の速度分布特性 を求めた結果から以下のことが明らかとなった.

（1）本プローブの風速に対する出力特性は風向を $-30^{\circ}<\theta<30^{\circ}$ に制限することで I 型熱線プローブと 同様に簡単な $\mathrm{n}$ 乗則に従う。

(2) 本研究の計則システムはパソコンを含むマト リックス参照法を適用したことで，I 型熱線プローブ 用の加熱回路を大きく改良することなく構築できる.

（3）簡単な較正法加精度の高い較正曲線，式(10) および式(11)が得られ，0.5\% FS 内という十分な精度で $U, V$ を求めることができる.

（4）本プローブは I 型熱線プローブと同程度の空間 分解能を持ち，これまで不可能であった固体壁近傍に おける 2 方向の速度成分の同時計測が可能となり, 測 定結果も精度の良いものが得られた.この結果は, 境 界層厚さが高だか $6[\mathrm{~mm}]$ 程度しかない境界層遷移の 研究に使用する上で, 本プローブが非常に有用なツー ルとなることを示している.

本プローブは空間分解能の高さから, 本研究が目的 とした遷移境界層での使用だけでなく，物体の近接伴 流や噴流など様々な剪断流れの計測においても有用と なることが期待される.

\section{文献}

(1) Tani, I. and Motohashi, T., Non-equilibrium behavior of turbulent boundary layer flows, Proceeding of Japan Acad, 61B(1985), pp. 333-340.

(2) Erm, L. P. and Joubert, P. N., Low-Reynolds-number turbulent boundary layers, Journal of Fluid Mechanics, Vol. 230 (1991), pp. 1-44.

(3) Spalart, P. R., Direct simulation of a turbulent boundary layer up to $R_{\theta}=1410$, Journal of Fluid Mechanics, Vol. 187 (1988), pp. 61- 98

(4) Spalding, D. B., A single formula for the law of the wall, Transaction of the ASME, Journal of Applied Mechanics, Vol. 28 (1961), pp. 444- 458.

(5) Purtell, L. P. et al., Turbulent boundary layer at low Reynolds number, Physics of Fluids, Vol. 24 (1981), pp. 802- 911. 